\title{
Preparation of Activated Carbon from Palm Oil Trunk Using H3PO4 as Activating Agent
}

\author{
Delviana Dwi Jaya ${ }^{1 *}$ Miftahul Khair ${ }^{2}$ \\ ${ }^{1}$ Chemistry Department, Math and Natural Science Faculty, Universitas Negeri Padang, Padang, Indonesia \\ ${ }^{2}$ Dept. of Biology, Faculty of Mathematics and Science (FMIPA), Universitas Negeri Padang, Padang, Indonesia \\ ${ }^{*}$ Corresponding author. Email: miftah@fmipa.unp.ac.id
}

\begin{abstract}
Activated carbon has been successfully made from oil palm trunk with carbonization temperature of $200^{\circ} \mathrm{C}$, held for 60 minutes, and chemical activation at room temperature by flowing $\mathrm{H} 3 \mathrm{PO} 415 \%$ as an activating agent. The proximate analysis results are yield of $78.9 \%$, moisture of $1.1 \%$, ash content of $4.1 \%$, fixed carbon of is $82.1 \%$ and iodine number of $761.02 \mathrm{mg} / \mathrm{g}$ which SNI standard.
\end{abstract}

KeyWord: activated carbon, oil palm trunk, H3PO4.

\section{INTRODUCTION}

One of biomass wastes not used optimally is oil palm trunk. When not utilized properly, waste oil palm trunk will further will give rise to waste problems. Effort have been done to conver oil palm trunk for the manufacture of activated charcoal ${ }^{1}$ or as charcoal ${ }^{2,3}$. The nature of the brittle wood and its low-calori showless fuel efficiency charcoal. ${ }^{4}$ Activation of oil palm trunk carbon will increase the surface area and adsorbtion capability for utlization of the Activated carbon (AC) produced for the purpose as water treatment adsorbent. The activation process on charcoal in general can be divided into three types, i.e physical, chemical and physicochemical activation.Chemical activation process is done by adding certain chemical compounds on charcoal. The chemical activation of oil palm trunk was reported by using with $\mathrm{ZnCl} 2$ as actvating agent ${ }^{5}$. The activation process physically can be done by heating charcoal in a furnace at a temperature between $600-900{ }^{\circ} \mathrm{C}^{6}$. A chemical compound that can be used as activating agent are $\mathrm{H} 2 \mathrm{O}, \mathrm{KCl}, \mathrm{NaCl}, \mathrm{ZnCl} 2, \mathrm{CaCl} 2, \mathrm{MgCl} 2$, $\mathrm{H} 3 \mathrm{PO} 4, \mathrm{Na} 2 \mathrm{CO} 3$ and other mineral salts ${ }^{6}$.

$\mathrm{H} 3 \mathrm{PO} 4$ is was reported for use as activating agent ${ }^{7}$, and the activated carbon obtained could effectively absorb chromium (VI). The aim of this research is to show the use of H3PO4 as activating agent for the preparation of oil palm trunk based activated carbon.

\section{MATERIALS AND METHODS}

The main material used in this study is the palm oil trunk obtained from palm oil mill Selago Makmur Plantation, Dharmasraya, West Sumatra. A solution of iodine (I2), Sodium Thiosulfate (Na2S2O3.5H2O), starch, $\mathrm{H} 3 \mathrm{PO} 4$, distilled water were used as it is. The prepared oil palm trunk was incorporated into a furnace for carbonization before activation with $\mathrm{H} 3 \mathrm{PO} 4$ solution of 5, 10 and $15 \%$ concentration. Carbonization was performed at temperature $200^{\circ} \mathrm{C}$ for 60 minutes. Activation was done by submersion and stirring of carbon at $110^{\circ} \mathrm{C}$ for 60 minutes, and cooling for 24 hours. 


\section{RESULT AND DISCUSSION}

\subsection{Result}

Table 1. Proximate analysis

\begin{tabular}{|c|c|c|c|c|c|c|}
\hline No & Product Sample & Yield & $\begin{array}{c}\text { Moisture } \\
\text { (SNI max } \\
15 \%)\end{array}$ & $\begin{array}{c}\text { Ash content } \\
(\%) \\
\text { (SNI max } \\
\mathbf{1 0 \%})\end{array}$ & $\begin{array}{c}\text { Fixed carbon } \\
(\text { SNI min } 65 \%)\end{array}$ & $\begin{array}{c}\text { Iodine number } \\
\text { (SNI min } 750 \\
\text { mg/g) }\end{array}$ \\
\hline 1 & Carbon & 56.7 & 6.9 & 15.9 & 62 & 364,34 \\
\hline 2 & $\begin{array}{c}\mathrm{AC} \text { with } \\
\text { activating agent } \\
\mathrm{H} 3 \mathrm{PO} 45 \%\end{array}$ & 75.5 & 6.1 & 4.6 & 76.4 & 501.25 \\
\hline 3 & $\begin{array}{c}\text { AC with } \\
\text { activating agent } \\
\text { H3PO4 10\% }\end{array}$ & 75.5 & 5.3 & 4.2 & 79.4 & 599.80 \\
\hline 4 & $\begin{array}{c}\text { AC with } \\
\text { activating agent } \\
\text { H3PO4 } 15 \%\end{array}$ & 75.5 & 1.1 & 4.1 & 82.1 & 761.02 \\
\hline
\end{tabular}




\subsection{Discussion}

\section{Carbonization}

Carbonization process can be carried out best at $200^{\circ} \mathrm{C}$ for 60 minutes. At this relatively low temperature of carbonization, the water content and other volatile compounds is assumed to be lost so that the opening of the pores of the carbon start to happen. This process produces pores but they are still relatively limited number. The data of proximate analysis after this carbonization process are then collected including the data after activation as shown in table 1.

\section{Activation}

The next step is the activation process in which the activation process was done chemically with $\mathrm{H} 3 \mathrm{PO} 4$ solution with concentration of 5,10 and $15 \%$ stirred at $110^{\circ} \mathrm{C}$ for 1 hour, and cooled at room temperatur for 24 hours. Carbon from oil palm trunks which have been activated was then tested for proximate analysis.

The yield which is mass ratio of the resulting AC and the raw material is in the range of 56-79\%. The moisture levels at different variations of concentration of 5, 10 and $15 \%$ ranges from $1.1 \%-6.9 \%$, which meet the standards set by SNI (Indonesian National Standard) maximum of $10 \%$. The highest concentration of $\mathrm{H} 3 \mathrm{PO} 4$ activating agent of $15 \%$ result in moisture of $1.1 \%$. This is a best result as the higher moisture can reduce the absorption capacity of of AC against liquids and gases. The ash content is a substance that remains after burning oil palm trunk and it is in the range of SNI standar.

\section{CONCLUSION}

The results showed that oil palm trunk can be used as the raw material of carbon manufacture, using carbonization temperature is $200^{\circ} \mathrm{C}$ with a time of 60 minutes. The activated carbon is obtained best by activation $\mathrm{H} 3 \mathrm{PO} 4$ with concentrations $15 \%$ stirring at $110^{\circ} \mathrm{C}$ for 1 hour. The $\mathrm{AC}$ produced at this condition meets the Indonesian National Standard (SNI), regarding moisture content, ash content, volatile, fixed carbon, and iodine number.

\section{REFERENCES}

[1] Siswoko, E., Mulyadi, A., Thamrin, B. Pendugaan kandungan karbon limbah batang pohon kelapa sawit peremajaan kebun di provinsi riau. J. Ilmu Lingkung. 11, 154-163 (2017).

[2] Abdullah, N. \& Sulaiman, F. The Oil Palm Wastes in Malaysia, Biomass Now-Sustainable Growth and Use. Biomass Now - Sustain. Growth Use 75-100 (2013). doi: $10.5772 / 55302$

[3] Dungani, R. et al. A review on quality enhancement of oil palm trunk waste by resin impregnation: Future materials. BioResources 8, 3136-3156 (2013).
The iodine number is one of the quality test of activated carbon products. The test is performed to determine the ability of activated carbon to absorb colored solutions. The iodine value obtained ranged between 364$76 \mathrm{mg} / \mathrm{g}$. That is, the only AC activated with 15\% H3PO4 concentration that meet SNI standard of iodine number more than $750 \mathrm{mg} / \mathrm{g}$. This shows that the higher the concentration of activating agent the greater the iodine number obtained. Results of AC from the oil palm trunk meet the SNI standards although the carbon form exessed the limit, however this confirms the effect of activation process.

[4] Hussein, M. Z., Zainal, Z., Ibrahim, R., Kheong, K. K. \& Muhammad, B. The preparation of activated carbons from chips of oil palm trunk catalysed by $\mathrm{ZnCl} 2$ /CO 2: Surface area and porosity studies. J. Chem. Technol. Biotechnol. 64, 35-40 (1995). Tajalli, A. B i o m a s s a 1. (2015).

[5] Abubakar Tadda, M. et al. A review on activated carbon: process, application and prospects PEATLAND HYDROLOGY View project Investigation on performance analysis of triple effect solar still coupled with evacuated tubes View project Journal of Advanced Civil Engineering Practice an. Journal of Advanced Civil Engineering Practice and Research 2, (2016).

[6] Karthikeyan, T., Rajgopal, S. \& Miranda, L. R. Chromium(VI) adsorption from aqueous solution by Hevea Brasilinesis sawdust activated carbon. J. Hazard. Mater. 124, 192-199 (2005). 